\title{
THE ARCHITECTURAL PROFESSION RESPONDS TO CONSTRUCTION MANAGEMENT AND DESIGN-BUILD: THE SPOTLIGHT ON AIA DOCUMENTS*
}

\author{
JUSTIN SWEeT† \\ I

\section{INTRODUCTION}

This article discusses construction management and design-build from the perspective of the architectural profession. ${ }^{1}$ Construction management and designbuild systems seek to bring organizational efficiency to a traditionally chaotic, undisciplined and inefficient building industry. These systems moved into the spotlight during a period of persistent inflation and tight money. They emerged at a time when people placed great reliance on computers and worshipped management methods associated with the Harvard Business School. This article preliminarily views construction management and design-build systems through the eyes of Playwright, Chronicler, and Prophet.

As playwright, the article views construction management and design-build systems through the eyes of an architect trained in the old school. The effect of the systems upon the architectural profession is then considered by looking at the objectives and activities of the American Institute of Architects (AIA). Finally, some predictions for the future of the architect and his relationship with other facets of the construction process are made.

\section{II}

\section{Back to the Graveyard: A One Act Fable in Three Scenes}

\section{Characters:}

FRANK L. WRIGHT, a famous American architect given temporary dispensation to return to the earth.

LESLIE BEATERS, disciple of Wright and principal partner of the architectural firm known as the Wright Foundation.

Copyright $(\mathcal{C} 1983$ by Justin Sweet

* The material dealing with the process by which AIA documents are made was gathered under a grant made by the National Science Foundation.

$\dagger$ Professor of Law, University of California (Berkeley).

1. This article does not discuss descriptions of and permutations in construction management or design-build systems, discussions which become dated as soon as they are published. Furthermore, the author is neither an architect nor a representative of the American Institute of Architects (AIA). 
T. BotTom Line, Office Manager and Risk Analyst for the Wright Foundation. CARL LARKIN, President of Larkin's Soap Company, a subsidiary of a multinational conglomerate.

CHUCK COMFORT, the Chief Executive Officer of HMS, a corporation which designs large-scale industrial and commercial projects and specializes in Construction Management.

Phil DiB, President of Root and Branch Corporation, an international energy resource development firm.

FIRST DRAFTSPERSON

ASSORTED DRAFTSPERSONS

\section{Scene I}

Architectural office in Taliesin, Wisconsin. Right two-thirds stage an outer office. Assorted draftspersons standing at their drafting tables, each with a computer terminal. Left one-third a plush executive office for the principal architect. Along the walls dramatic portraits of the Foundation's founder, Frank L. Wright, Japanese prints, and blown-up photographs of famous Wright projects. WRIGHT enters. Flowing white hair. Cape and broad-brimmed hat. Malacca cane.

First Draftsperson: Mr. Wright has come back! (Calling to Beaters at his desk in the executive office) Mr. Beaters!

BEATERS (entering the outer office): Mr. Wright! We prayed, burned incense and chanted Welsh poetry. We even...

WRIGHT (interrupting): Hogwash! As the greatest American architect, if not the greatest in the world, (looks at his portrait and his works admiringly) I cannot waste time listening to cant. You know how I despise dishonesty in people and design. Also I can't be sure how long I'll be allowed to stay here on earth. Let's get to work.

BEATERS and WRIGHT enter executive office.

BEATERS: Well, Mr. Wright. We have three commissions we'd like you to work on. The first is a Russian Hill mansion in San Francisco we're designing for film director Josef von Feldmann. The second is the headquarters for the Larkin Soap Company. The third is the administration building for Four Mile Hill, a nuclear plant being built by the New Mexico Power and Light Company.

You must meet Bottom Line, our Business Manager and Risk Analyst (the latter has been sitting at his computer terminal). Mr. Line just returned from a Loss Prevention Seminar put on by Winner/Kneebone, our insurance advisor.

LiNE: I am honored to meet you, Mr. Wright. (to himself: What will this mean to our profit margin?' He had a terrible reputation for massive cost overruns.) I've always admired the honesty of your design. You fought the philistines and barbarians.

WRIGHT: Thanks, Line. Integrity is a priceless commodity. Let's look at the schematics on the Russian Hill job.

LINE: But first, Mr. Wright, I want to go over our contract with the client and the construction documents. They're AIA Documents. At the Loss Prevention Seminars we were instructed to use them. 
WRIGHT: The AIA is run by old men afraid to go out without their rubbers. It took them a long time to honor me. I was almost eighty.

LINE: But they really have kept the architect out of trouble. Would you like to go over the Documents?

WRIGHT: No, just answer a few questions for me, young man.

LINE: Yes, sir.

WRIGHT: Do I still have general supervision of the work?

LINE: Not exactly. We had to replace "general supervision of the work" with "periodic observations" because we were getting sued by workers.

WRIGHT: I assume that I still can refuse to approve subcontractors, remove an incompetent worker or superintendent, or stop the work. ${ }^{2}$

LiNE: Well, there have been some other changes since you left us, Mr. Wright. The Architect can't be a Master Builder. Liability is a big problem. One out of three architects will be sued in 1982. ${ }^{3}$ Risk Analysts protect architects so they can concentrate on design. If your clients don't follow our advice your Errors and Omissions premiums will soar. Even if you can pay them, you'll become uncompetitive. You'll lose to package builders. The Documents do fudge on traditional powers. We advise more and approve less. The Documents simply took away powers which architects didn't use much anyway, such as approving subcontractors, removing the superintendent and stopping the work. You have to . . .

WRIGHT (intermupting): I know, watch the bottom line. But let me tell you something, young man. I learned construction materials and techniques on the job, climbing on the scaffolds and working with the workers. Why, in 1938, when I was already 70 , I scrambled along the scaffolds on the Johnson Building. When I was on the site, everyone paid attention. If I thought of a better construction technique, I ordered the superintendent to use it. If I thought a change in design would improve aesthetics or structural stability, I ordered it. If the work was being botched, I would shut the project down until they agreed to shape up. I am judged by the end product. When I built La Miniatura for Mrs. Millard in California I learned what happened when you don't keep a careful eye on the contractor. They blamed me when the roof leaked! That damned contractor tried to skimp on materials and labor. Contractors as a class are criminally ignorant or dishonest. Your AIA Documents reduce me to a figurehead. The Architect is no longer captain of the ship. These loss prevention insurance people and lawyers run the show. Who are they? What qualifies them to take over? The Architect alone can create a better life, an organic life in accord with harmony and nature. (BEATERS looks up at the ceiling and BOTTOM peers at his digital watch.)

WRIGHT (his reverie over): Now, what about the Soap Company job?

BEATERS: We have a meeting tomorrow with Mr. Larkin. Let's have lunch.

All exit.

2. Frank Lloyd Wright had these powers in the Agreement Between Contractor and Owner for Construction of Usonian Buildings, arts. B, 12, 30, 32.

3. Wall St. J., Feb. 12, 1982, at 27, col. 4 (western ed.). 


\section{Scene II}

An executive office suite. WRIGHT, BEATERs and a well dressed executive, MR. LARKIN, sit around a massive conference table.

BEATERS: Mr. Larkin, Mr. Wright is going to be working with us on this job. Isn't it exciting! He's taking over design.

LARKIN: What a treasured moment for me. I've always admired your work, Mr. Wright. It's creative, modern, American, in conformity with nature.

WRIGHT: True. Let's get to the job.

LARKIN: Mr. Wright, I want you to meet Chuck CoMForT, the Construction Manager. He is the chief executive officer of HMS, one of the best construction management firms in the country. (presses button) CoMFORT enters complete with leather briefcase and calculator wrist watch. He appears to be businesslike, confident and efficient.

COMFORT: What an honor. I did a paper on you in architecture school before I got my Harvard M.B.A. I can't believe I'm really in the same room with Frank L. Wright. It's the high point of my life!

WRIGHT (suspiciously): What do you do, sir? What is a Construction Manager? What do you manage? Are you an architect? Or are you a contractor?

LARKIN: Let me explain, Mr. Wright. Time really means money these days. If we can reduce the time to complete a project, we can save big money. The CM helps the designer. In the design phase, he has up-to-date information on the labor market, contractors, construction methods, supplier reliability, material availability and finances. He's tops at cost estimates. Without a good CM you can't Fast Track the job.

COMFORT: We help start preliminary site work before the design is finished. That's Fast Tracking. We know how and when to order material. We create a CPM. We organize inputs and obtain feedback.

WRIGHT: (to himself): I thought I had the monopoly on jargon')

Beaters: Mr. Wright, CPM is Critical Path Method, a logical computer-aided system to move the job along quickly.

WRIGHT: I know. In my day it used to be called common sense. Working too fast can mean poorer work and corner-cutting. Does this system mean that I can't make design changes?

COMFORT: As long as it's within the parameters of the original design. But large changes are not possible under Fast Track.

WRight: I know. Time is money. What this CM does could be done by a good architect.

COMFORT: That's true, but unfortunately most architects don't understand modern management techniques. They can't handle cost estimates, scheduling, construction techniques. They don't know the trades like we do. We can evaluate bids and bidders better. We also guarantee a maximum price. That's a GMP. Sometimes we hire the trades and even do work with our own forces. 
WRIGHT: Sounds like you're a general contractor to me. ${ }^{4}$ What do you do on the site?

COMFORT: I revise and police the CPM, order changes, check quality, create and police a safety program (OSHA, ${ }^{5}$ you know), pay contractors, monitor the cash flow, and check on product warranties. But I do not interpret the documents or judge performance. That's for the architect. I just help make the job more efficient.

WRIGHT (to himself): (Giving the contractor inspection rights and payment authorization? That's dangerous. And giving him these powers to check on his own men is like putting the fox in charge of the chicken coop.) What's OSHA? Don't bother to explain. A good architect can do these things, CoMFor'T. I suspect I'm being reduced to a subordinate role, to a member of a committee, to part of a bureaucracy. Only individual architects gifted with creativity and vision can build great projects, lead Mankind to a better life, create a humane world . . .

BEATERs (intermupting): Mr. Wright, we've got 15 minutes to catch the plane. We must meet Phil DiB from Root and Branch. Goodbye, Chuck. Goodbye, Mr. Larkin.

Exit WRIGHT and BEATERS.

\section{Scene III}

Well-appointed, businesslike office, Southern California style. Renderings of completed projects, mostly nuclear facilities and oil refineries hang on walls. Large banner on the wall reads "On time-on budget." PHIL DIB, BEATERs and WRIGHT enter and seat themselves around a modern conference table.

DiB: What an honor: One of the reasons we were selected was the reputation for high quality design of the Wright Foundation. But it's an unexpected blessing to have you personally, Mr. Wright. (to himself: We've got to really watch costs now. His famous Imperial Hotel went three times budget.)

WRIGHT: I'd like to meet the client.

BEATERS: Mr. Wright, this is a different commission. We weren't chosen by the New Mexico Public Utility. They picked Root and Branch to be A/E, CM and Contractor. It's a DB project. The client gives general performance specifications to the $\mathrm{DB}$ and the $\mathrm{DB}$ designs through the subs or his $\mathrm{A} / \mathrm{E}$. The $\mathrm{DB}$ builds the whole project and turns it over to the owner. DB centralizes responsibility. No more fighting over whether it was poor design or poor construction. It's also easier to Fast Track.

You see, Mr. Wright, large institutional clients want a guaranteed price and technical skill.

WRIGHT: It was bad enough to work with the contractor. Now we work for the contractor.

4. Several courts have for various reasons likened the CM to a contractor. See, e.g., Everette v. Alyeska Pipeline Serv. Co., 614 P.2d 1341 (Alaska 1980) (liability to worker); City of Inglewood v. Superior Court, 7 Cal. 3d 861, 866, 500 P.2d 601, 604, 103 Cal. Rptr. 689, 692 (1972) (competitive bidding); Lemmer v. IDS Properties, Inc., 304 N.W.2d 864, 866 (Minn. 1980) (joint tortfeasor with owner); Kenny v. George A. Fuller Co., 87 A.D.2d 183, 450 N.Y.S.2d 551 (1982) (strict liability to worker); Carollo v. Tishman Constr. \& Research Co., 109 Misc. 2d 506, 508-09, 440 N.Y.S.2d 437, 439-40 (Sup. Ct. 1981) (strict liability to worker).

5. Occupational Safety and Health Act, 29 U.S.C. $\S \S 651-678$ (1976) (regulating workplace safety). 
BeAters: That's right. But they're not just ordinary contractors. They're talented, efficient people who really know how to put a project together. They appreciate creative design, but we do have to watch costs.

WRIGHT: Who approves the design?

DiB: Well, we have a system.

WRIGHT: I thought you would.

DiB: The R \& B In Process Design Committee injects input and we get feedback from the owner's A/E department. The $R \& B$ Final Design Team reviews it. Ultimately, the Owner approves the design. But we would pay very close attention to your ideas. Keep in mind, we're trying to ease your burden so that you can use your creative talent to design something great.

Wright: Seems as if I am being "helped" to death. I've lost all control. I'd really be working for you. I'd be part of a team, correct?

DiB: Essentially that's right.

WRIGHT: I think I've seen enough.

WRIGHT shuffles out of the office and trudges toward his grave in Taliesin East.

III

\section{The Architectural Profession Responds}

This section judges the effect of construction management and design-build upon the architectural profession by looking briefly at the American Institute of Architects, ${ }^{6}$ its objectives, and one of its principal activities - the publication of documents. ${ }^{7}$

AIA has developed a successful system of structuring design and construction relationships. AIA prepares, publishes, and distributes contract forms tailored to principal construction activities. Some reasons for its success are:

(1) AIA cosponsored the first national construction contract in 1888 , published its first document in 1911, and has published continually since then;

(2) the architect is in the position, particularly in traditional construction, to suggest which documents the owner should use;

(3) the architect is a professional with a reputation for neutrality in an industry dominated by less educated contractors ${ }^{8}$ and

(4) the construction industry requires some commonly accepted construction contract forms which provide the connectors, the "plug compatability," which make it possible to gather efficiently a group of specialized entities for a particular project, to create a "quasi-firm."

AIA's most important documents are A-101, A-201 and B-141. The first two,

6. AIA is a voluntary organization. No one need join. AIA must convince architects that it merits their support.

7. AIA believes that one service highly prized by its members is document making. An internal AIA report, AIA Analysis of Documents Program (undated but circulated in 1980), designed to obtain more support for the Documents Division, stated: "AIA documents have a prominent place in the new membership drive brochure ('With AIA After Your Name . . .), where it is recognized that the documents and the [AIA] Handbook are one of the most important service[s] offered to the practitioner by AIA." Id. at 40-23.

8. Much of this is changing as contractor executives are increasingly well-trained individuals with M.B.A.'s who need a variety of management skills for larger projects. 
important components of the A-Series documents, create a detailed structure for the construction contract. The third, leader of the B-Series documents, structures the architect-client relationship. Even though contracting parties need not use the documents, they do use them, ${ }^{9}$ and they are used largely unchanged. ${ }^{10}$

AIA makes documents for a number of reasons: documents make money; ${ }^{11}$ documents provide justification for AIA's claim, as the representative of the architectural profession, to be the leader in the construction industry; documents establish industry standards and customs. And perhaps most importantly to architect members, they help architects, particularly those who practice alone or in small firms to:

(1) provide a negotiation counterweight when they deal with a client who has superior bargaining power;

(2) reduce legal expenses necessarily incurred in drafting a contract or reviewing a contract submitted by the client;

(3) collect their fees when projects are abandoned due to lack of a bid in line with the owner's budget or financing difficulties;

(4) change undesirable rules of law, such as those which give the client ownership of the plans and specifications; and

(5) avoid or at least reduce the risk of liability to the client and third parties.

Goals may clash, however. For example, in 1961, the AIA B-Series documents were changed to protect the architect's fee and reduce liability. This was done at the cost of diminishing the status of the site architect. ${ }^{12}$

AIA ceaselessly points to document making as a public service. ${ }^{13}$ Indeed, AIA documents are important. They do a good job of providing order in an industry which desperately needs it. As already suggested, AIA uses its documents to serve its members and the architectural profession, but an understanding of AIA's reaction to construction management and design-build requires a study of AIA "policy." AIA expresses its policies in its resolutions, activities, periodicals, publications, and most importantly for our purposes, in its documents. Since AIA poli-

9. Some reasons why they are used are: they have a good reputation for fairness, completeness and clarity; they are familiar to industry participants; for a contractor they are always better than an ownerdrafted form; architects suggest they be used, in part because they protect the architect; and they are much cheaper and probably better than the product which would result from hiring (and educating) the average lawyer to draft the contract.

10. A book to be published by McGraw-Hill, Construction Management Agreements, contains two chapters by Alan B. Stover, General Counsel of AIA. He states that AIA documents "are most often used without extensive modification." Stover, Standard Industry Constnution Management Contract Forms, in ConStruction Management Agreements (forthcoming). (I would like to thank Mr. Stover for kindly sending me his chapters in manuscript form.) An unpublished survey of those who use AIA documents in Northern California and Wisconsin concluded that on the whole the documents are used largely unchanged. Certain sensitive clauses were modified occasionally, such as those dealing with changes, payment, architect responsibility, arbitration, and subcontractors. J. SWEET, LAWMAKING BY STANDARD FORMS: A Study OF AIA Contract Documents 124-33 (1978).

11. This is not the appropriate place to supply in-depth documentation on this point. Certainly AIA believes this is a profitable activity. This is explored in detail in the unpublished study of AIA's document making. J. SWEET, supra note 10.

12. Sweet, Site Archilects and Construction Workers: Brothers and Keepers or Strangers, 28 EMORY L.J. 291, 302-11 (1979); see also AIA HANDBOOK ch. 9 at 4.5 (1970).

13. See AIA HANDBOOK ch. 3 at 3-20 (1981). 
cies are expressed in its documents, ${ }^{14}$ AIA seeks to have the documents used as much as possible. ${ }^{15}$

AIA favors the single contract system over the multiple prime or separate contract system because AIA believes the single contract system is more efficient. ${ }^{16}$ Although the documents deal marginally with separate contracts, they operate on the assumption that the single contract system will be used. (It will be shown below, however, that the new construction management and design-build systems, particularly the former, forced AIA to expand its document horizons beyond the traditional single contract system). AIA prefers that design be separate from construction, and that the designer be an independent professional adviser to the owner without an entrepreneurial stake in the project. ${ }^{17}$ AIA favors arbitration under the Construction Industry Rules of the American Arbitration Association. AIA strenuously opposes consolidation of separate arbitrations and joinder of third parties to existing arbitrations unless all parties consent. ${ }^{18}$ AIA opposes limitations on contractual liability in design professional contracts. ${ }^{19}$ Most of all, it insists that the contractor and not the architect be solely responsible for construction techniques. ${ }^{20}$

Note, however, that there are other organizations which play a role in the ASeries documents. While AIA has never sought endorsement of its B-Series documents, those dealing with design services, AIA has in the past sought endorsement of its A-series construction documents, such as A-101/201, from many contractor trade associations. ${ }^{21}$ This could delay publication and marginally reduce AIA control. Since 1966, AIA has sought endorsement only from the Associated General Contractors (AGC), a trade association composed of prime contractors. The tardy scholarly recognition of the importance of AIA documents, and of trade

14. An incidental use of documents as "policy" occurs in discussions among the various construction industry associations. If one association wishes to argue for a particular clause or policy, a representative of that association may direct attention to a document published by the association he is seeking to convince as "evidence" of the latter's policy.

15. AIA worked with the U.S. Department of Health, Education and Welfare (HEW) and published document A201/SC, Federal Supplemental Conditions, purportedly usable for HEW federally assisted construction projects. See AIA HANDBOOK ch, 4 (1981). AIA officials have given speeches to state and local groups urging use of AIA documents.

16. AIA HANDBOOK ch. 16 at 6 (1971).

17. American Institute of Architects, The Standards of Ethical Practice, Doc. J330 (June 1974), indicated that the architect must not engage in building contracting for profit but should only work as a professional for professional compensation. Currently, AIA's voluntary ethical standards do not deal specifically with this issue. American Institute of Architects, Ethical Principles, Doc. 6J400 (Mar. 1981), states that architects should "accept the primacy of learned and uncompromised professional judgment over any other motivation. . .," that any potential conflict of interest be disclosed, and that architects should not violate a position of trust "to further their own business' interests."

18. American Institute of Architects, General Conditions of the Contract for Construction, Doc. A201, art 7.9.1 (Aug. 1976) [hereinafter cited as AIA General Conditions], reprinted in BusINEsSMAN's Guide to Construction 198 (1980).

19. An article by Arthur T. Kornblut attacked the validity of such clauses. Kornblut, Limitation of Liability-Engineers' Panacea or Placebo, Actual SPecifying Engineer, Mar. 1974. Kornblut, formerly Administrator of the AIA's Commission on Professional Practice, is now a member of a law firm closely associated with AIA's insurance counselor. His views are usually aligned with those of AIA.

20. See AIA General Conditions, supra note 18, art. 2.

21. The last AIA General Conditions, A201 with multiple association endorsement was endorsed in 1961 by eight associations. 
association forms in general, ${ }^{22}$ and the assumption currently made that these documents result from "negotiation" between $\mathrm{AIA}$ and $\mathrm{AGC}^{23}$ warrant a description of the process by which the current document A-201 was finalized. ${ }^{24}$

First, AGC was given drafts of the AIA documents and asked to comment. AGC then submitted a lengthy list of objections dealing mainly with arbitration, subcontractors, insurance, and remedies for delayed progress payments. In the course of resolving these conflicts it appeared that AIA possessed roughly seventy to eighty percent of the bargaining chips. When at one stage AGC threatened not to endorse the AIA drafts, AIA took the position that the documents would be published without AGC endorsement. For AIA, such a refusal by AGC to endorse, although unfortunate, would be far less devastating than active opposition such as that mounted by AGC in 1966 in a dispute over an indemnity clause.

In the end, some of AGC's demands were met, particularly the demands AGC had made year after year without success. In addition, some AGC demands neatly coincided with AIA interests. For example, AGC wanted to eliminate the architect's power to remove the prime contractor's superintendent, a change compatible with AIA's program to diminish the architect's overall control and to minimize liability. ${ }^{25}$

Even though it knew its power in this revision process was limited, AGC attributed its participation and endorsement to the fact that the AIA documents were better than documents supplied by the owners. There is a second reason for AGC's participation in the drafting process, one that relates to the new methods of construction to which this symposium is directed. In AGC's opinion, the future expansion of the construction management and design-build systems will lead to increased use of AGC documents, since a contractor CM may get to the owner before the architect does and a design-build contractor will get to the owner without any architect acting as intermediary. ${ }^{26}$ Cooperation may lead to AIA endorsement of AGC Documents. ${ }^{27}$

In addition to AGC, two other organizations, the Associated Specialty Contractors (ASC), and the American Subcontractors Association (ASA), were given drafts of AIA documents and the opportunity to comment, but these two groups were not asked to give their endorsements. Under the traditional construction system, prime contractors have greater bargaining power than subcontractors when the subcontracts are made. Subcontractor groups complain to AIA of mistreatment by prime contractors and request that architects, as surrogates for owners who need competent and fairly treated subcontractors, protect them. Sub-

22. L. Fuller, Basic Contract Law 180 (1947); I. Macneil, Cases and Materials on ConTRACTS 446-47 (2d ed. 1978); Atiyah, Book Review, 85 L.Q. REv. 564 (1969). For a discussion of the German law on the same topic, see Dawson, Unconscionability, 89 HARV. L. REV. 1041, 1104, 1107 (1976).

23. I. MACNeIL, supra note 22; Note, Archilectural Malpractice: A Contract-Based Approach, 92 HARV. L. REV. 1075, 1093 n.124 (1979); see also Sweet, supra note 12, at 291, 319 n.123 (1979).

24. The author's personal observation of this process provides the basis for its description.

25. AlA General Conditions, supra note 18, art. 4.9.1, deleted this power, which had been included in the previous A-201 published in 1970.

26. Reed, CM's Confict of Interest Question, CONSTruCtOR, June 1980, at 17-19.

27. This has not yet happened. AIA commented on AGC's 6b (Contractor-Architect Agreement) but did not endorse. 
contractor groups also champion methods other than the traditional single contract organizational system. Subcontractors dislike dealing with prime contractors. Rather, they prefer to deal with the owner (under separate or multiple prime contracts), or with a CM, as indicated by the complaints subcontractors lodge against the prime contractors. Prime contractors, subcontractors assert, force down subcontractor bids, push too much responsibility on the subcontractors, invest so little in the project that they do not make the maximum effort to make the money flow down to the subcontractor, divert funds, and are "brokers" who make money on the efforts of productive subcontractors.

The spotlight on construction management and design-build in the 1970's forced AIA and AGC to respond. Even though each preferred the traditional method with its single contract and division between design and construction, each sought to help its members get a bigger part of the new construction management business. Also, AIA needed to modernize to preserve its document domination. These new methods gave AGC an opening for its documents. Each group published documents dealing with the $\mathrm{CM},{ }^{28}$ and AGC published a series for designbuild. $^{29}$ Neither endorsed the documents of the other.

As the groups shifted gears, new issues emerged:

(1) Should the CM have an architectural or a contracting background? (Members of which organization would have the inside track in getting this new business?) ${ }^{30}$

(2) What will be the relationship between architect and CM in the design and, more importantly, the construction phase? (Who does what and who has higher status?) $)^{31}$

(3) What is the nature of the relationship when a design-builder hires an architect? ${ }^{32}$ (Can AIA members be protected from unfair - at least to AIA - contract terms, liability exposure and reduced professional status?) ${ }^{33}$

The AIA "family" of CM documents makes the CM an independent profes-

28. The principal members of AIA's CM family are AIA Docs. A101/CM, A201/CM, B141/CM, B801, all published in 1980. AGC's CM documents are Docs. 8 (1980), 8a, (1977), 8d (1979), and 520 (1980). AGC's CM documents are being renumbered and revised. Doc. 8 will become 500, 8A will become 501 , and $8 \mathrm{~d}$ will become 510 .

29. AGC Docs. 6, 6b, 410 and 430. AGC documents are being renumbered and revised. Doc. 6 will become 400 and $6 \mathrm{~b}$ will become 420 . Docs. 450 and $450-1$ will be issued, dealing with subcontracts with (450) or without (450-1) the subcontractor furnishing design. They will be used with 430 , the General Conditions for Subcontracts. AIA is working on design-build documents at present.

30. See Hart, Construction Management- "CM for Short"- The New Name for an Old Game, 8 FORUM 210 , 213-15 (1972); Lammers, Construction Manager: More Than a Hard-Hat Job, Am. Inst. ArchiteCTS J., May 1971, at 31, 31-32; Reed, supra note 26; Wagner, Where, Oh Where, Are the Management Skills?, ARCHITECTURAL REC., Dec. 1971, at 9; see also Stover, supra note 10.

31. See C. Thomsen, CM: Developing, Marketing \& Delivering Construction ManageMENT SER VICEs 85, 117 (1982). Thomsen notes there is no contract between A/E and CM and suggests a memo of understanding. See also Koehler, Where the Office Becomes a Classroom for Continuing Education, AM. INST. ARChitects J., May 1971, at 33; Note, The Roles of Architect and Coniractor in Construction Management, 6 MICH J.L. REF. 447, 457-58 (1973).

32. Associated General Contractors, Standard Form of Agreement Between Contractor and Architect, Doc. $6 \mathrm{~b}$ (Jan. 1979).

33. AIA suggested AGC make modifications in AGC's $6 \mathrm{~b}$ dealing with an architect-contractor relationship. 
sional advisor much like an architect, rather than a profit-making contractor. ${ }^{34}$ The AIA's CM does not guarantee a maximum price (GMP) and does no construction work on the project. ${ }^{35} \mathrm{AGC}$, on the other hand, provides owner protection by creating a mechanism for a GMP when cost-type contracts are used. ${ }^{36}$ Also, AGC allows the CM to do some of the construction work. Work performed by the trade contractors (specialty contractors who would be denominated subcontractors in a traditional system) can be hired either by the owner, with the CM coordinating the work, or by the CM directly. ${ }^{37}$

Each group champions its own documents. ${ }^{38}$ AIA asserts that the AGC CM system creates serious conflicts of interest: in the design phase and, to a greater extent, in the construction phase, the CM who guarantees a maximum price and does part of the work himself may not be influenced solely by the best interests of the owner. Such a CM, according to AIA, may not develop the most accurate target price under a cost incentive contract in order to make more savings available to him if the cost comes in under the target price. AIA asserts that the contractor CM, unlike the architect CM, may not be accustomed to giving undivided professional attention to the owner's best interests. More importantly, AIA contends that the CM may take the best work for himself, he may not get the best subcontractor prices, and he may not judge the work of the contractors impartially, let alone fairly evaluate his own work.

- AGC contends that these potential conflicts of interest can adequately be dealt with by disclosure, a point AIA does not concede. AGC also argues that owners who demand a GMP are generally sophisticated institutional owners who are able to protect themselves and are willing to run the risk of potential conflicts of interest in order to take advantage of a capable, efficient construction manager. ${ }^{39}$

AGC counterattacks by also invoking conflict of interest. It argues that a CM

34. American Institute of Architects, Standard Form of Agreement Between Owner and Construction Manager, Doc B801 (Dec. 1980), reprinted in Businessman's GuIDE TO CONSTR uCTION 238 (1980).

35. Id. ; see supra note 17 for AIA's position on ethical issues relating to the CM.

36. Associated General Contractors, Standard Form of Agreement Between Owner and Construction Manager, Docs. 8 (1980) [hereinafter cited as AGC 1980 GMP Agreement], reprinted in BuSINESSMAN's Guide to Construction 248 (1980); Associated General Contractors, Amendment to Owner-Construction Manager Contract, Doc. 8a (June 1980), reprinted in Businessman's Guide to Construction 264 (1980).

37. Associated General Contractors, Standard Form of Agreement Between Owner and Construction Manager, Doc. 8d (June 1979) [hereinafter cited as AGC CM Agreement], is used when the owner awards all trade contracts. When the CM awards them, AGC Doc. 8 is used. AGC 1980 GMP Agreement, supra note 36. In either case, Associated General Contractors, General Conditions for Trade Contractors Under Construction Management Agreements, Doc. 520 (July 1980) [hereinafter cited as AGC Trade Contractors], provides the general conditions for trade contracts.

38. See Reed, supra note 26. The views expressed by Alan B. Stover, reflect AIA views despite the usual disclaimer that Stover's views are his own and "do not necessarily reflect positions or policies" of AIA. Stover, supra note 10. While Director of Documents, Stover was the major AIA staff person involved in the documents-making process, and he is now AIA General Counsel. Based upon this and my many conversations with him, I believe his views are those of the AIA

39. Many construction management cases do involve owners of this type. See, e.g., Everette v. Alyeska Pipeline Serv. Co., 614 P.2d 13, 41 (Alaska 1980); Mackey v. Campbell Constr. Co., 101 Cal. App. 3d 774, 162 Cal. Rptr. 64 (1980). In a large project built for the U.S. General Services Administration (GSA), the GSA and the prime contractor each had its own CM. The dispute was which CM had a duty to check on safety. DiSalvatore v. United States, 456 F. Supp. 1079 (E.D. Pa. 1978) (denial of motion for summary judgment), 472 F. Supp. 816 (E.D. Pa. 1979) (disposition at trial), appeal dismissed, 622 F.2d 578 (3d Cir 1980). 
who is part of the architect's organization, a "single-point" A/E-CM, cannot give the type of independent evaluation of design and administration that the owner needs. ${ }^{40}$ The Construction Management Documents published by the National Society of Professional Engineers and the American Consulting Engineers Council (NSPE/ACEC) create a Single Point A/E-CM, ${ }^{41}$ and the AIA document can be modified to put the architect and CM in the same organization. ${ }^{42}$ AIA responds that an owner who hires one organization for both architectural services and construction management has not paid for separate, impartial evaluation and presumably does not want it. Although it may be true that AIA believes its version is best for the owner, AIA cannot be uninfluenced by the likelihood that use of its documents will generate business for its members and advance AIA policies contained in AIA documents.

In defining the relationship between architect and CM, each group, AIA and AGC, uses its own documents to enhance the prestige of its members. While AIA gives the CM important responsibilities in design and construction, the architect retains the dominant position. ${ }^{43}$ On the other hand, AGC clearly diminishes the architect's status: AGC requires that the architect and trade contractors communicate through the $\mathrm{CM},{ }^{44}$ that site facilities be given to the architect only if directed by the $\mathrm{CM},{ }^{45}$ and most disparagingly, that the CM is the leader of the construction team of which the architect is only a member. ${ }^{46}$

With respect to design-build, AGC jolted AIA by announcing that it was preparing its own document to be used when the design-builder retains an architect. When AGC invited AIA to comment, AIA threatened to deny AGC permission to use its "copyrighted" provisions unless the AGC document was satisfactory to AIA. ${ }^{47}$ Ultimately, AIA allowed AGC to use its copyrighted language, but since AIA felt the document was unfair to architects, it decided not to endorse it.

40. A professional design-build, single point contract (A/E-CM) combines design and construction management in a single contract, with the owner letting construction contracts directly. One engineer suggests that the design may not be as complete if the A/E knows he will be involved in site management. This can lead, he says, to large bid contingencies, costly changes, and too close A/E-contractor relationships. Hester, Altemative Construction Quality Assurance Programs, $105 \mathrm{~J}$. Construction Division, Proc. AM. SOC'Y CIV. ENGINEERS 192 (1979).

41. Standard Form of Agreement Between Owner and Project Manager for Professional Services, NSPE/ACEC Pub. No. 1910-15 (1977).

42. Stover, supra note 10, ch. 4.

43. AIA General Conditions, supra note 18, art 2. Ironically this can create liability exposure, something AIA has sought to avoid by reducing the architect's site powers. See supra note 12.

44. AGC Trade Contractors, supra note 37 , arts. 2.2.4, 3.2.8, 5.16.1.

45. Id. arts. 3.2.1.

46. AGC 1980 GMP Agreement, supra note 36, art 1.1; AGC CM Agreement, supra note 37, art. 1.1; see C. ThOMSEN, supra note 31 , at 85 (refers to CM as the "captain" of the team); see also Lammers, supra note 30 , at 31 , which states that in design the CM "rounds out" the design team, but in construction the CM takes the leadership role.

47. A fascinating and troublesome question beyond the scope of this article is the extent to which AIA document language is protected by copyright law. It is clear that AIA believes no one can copy its language for any reason (perhaps "fair use" would be excluded). Those who deal with AIA seem to agree. AGC sought AIA's permission to use AIA language for its Doc. 6b.

The architectural profession fights design-build in other ways. Georgia upheld a licensing regulation which limits the work experience credit given an architect for design-build practice to two of the required three years. Wise v. State Bd. for Examination, $247 \mathrm{Ga} .206,208,274$ S.E.2d 544, 545.46 (1981). Designbuild licensing is discussed in Note, Design-Build Contracts in Virginia, 14 U. RiCH. L. REv. 791 (1980). 
To sum up, AIA would probably have preferred that construction management and design-build systems had not received the publicity given them in the early 1970's. This publicity spotlighted structural deficiencies in the traditional system, undesirable attributes of the construction industry, and inadequacies in the architectural profession. ${ }^{48}$ It was inevitable that construction management and design-build would diminish the architect's stature. But once the spotlight fell on these new methods, AIA sought to get construction management business for its own members, to preserve as best it could the architect's status when a CM is used, and to protect architects who work for design-builders. Finally, AIA published CM documents in order to keep its documents system up-to-date and to preserve its document hegemony. ${ }^{49}$

\section{IV \\ The Future}

What will be the long-range effect of construction management and designbuild upon the architectural profession? Is construction management an intermediate step to a total design-build system ${ }^{50}$ Will architects work no longer for themselves, and work instead for: (1) public agencies; (2) institutional owners; (3) developer builders; (4) design builders; (5) large multifunction architectural organizations? Certainly the growth of these non-traditional systems will diminish the importance of the architect as an independent professional advisor who works for a fee and does not take entrepreneurial risks.

Yet the independent architect who practices in a small office is not on the road to extinction. His world, consisting largely of small or middle-sized commercial structures and occasional residences, does not demand or justify the extremely efficient, management-oriented $\mathrm{CM}^{51}$ or the centralized responsibility of the highly specialized designer-builder (DB). His world is not that of CPMs, GMPs, CMs or DBs, the world of the Bechtels, the Turners or the SOMs. These new movements have passed him by just as they have passed by the many architects not involved in projects for which these new methods seem essential. Important as these new systems are, and as much as AIA has sought to deal with them, they will not eliminate the independent architect.

Clearly, more architects will work for others not only because of these new methods, but also to avoid the higher overhead, larger insurance premiums, tax considerations and increased liability facing the independent architect. These

48. See Hastings, Proposal: A New and Comprehensive System for Design and Delivery of Buildings, ARchITECTURAL ReC., Nov. 1968, at 135; Lammers, supra note 30; Wagner, supra note 30.

49. Another topic beyond the scope of this paper is the antitrust aspects of AIA documents. The AIA documents can be considered anticompetitive; nevertheless, in highly competitive industries such as design and construction, they help competition by standardizing many provisions, which can focus competition on the variable ones. But what about dominating the market of making standardized construction forms? See supra note 47.

50. See Arnold, CM Leads to Design-Construct, ConstruCtor, Jan. 1972, at 24; Hart, supra note 30, at 215.

51. One commentator, writing in 1972 , thought it would take a $\$ 5,000,000$ project to justify using a CM. Hart, supra note 30, at 224. 
drawbacks have led to a greater concentration of architects both in other professions and in business organizations. This will mean fewer architects will practice independently in small offices engaged in work commissioned by clients. Yet we will see a continual demand for services which can best be performed by independent architects. Also, there will be a never-ending supply of young architects who choose to practice independently because of the importance they place on their control over design and their crusading zeal for using architecture as the instrument for better and more gracious living. The combination means that the independent architect practicing by himself or herself or in a small group will not die out.

Nonetheless, construction management and design-build have exposed weaknesses in the architectural profession. Architectural educators will begin to pay attention to those skills which have been lacking in the profession and which good CMs supply. Architects who do not wish to become employees or even principals in gigantic architectural/engineering firms will develop new forms, such as loose consortia, which will enable them to preserve their autonomy, yet take advantage of management and planning techniques. Such consortia will pilot them through the shoals of liability, fee risks and government regulation. In effect, there will be AMs: Architectural Managers. Finally, more architectural/engineering "firms" will appear to provide a variety of special skills, the lack of which has generated the need for construction management and design-build systems. While the architectural profession as we have known it will not disappear, the variations of the construction management and design-build systems from the traditional methods will leave an indelible mark on the profession. 